\title{
On the usefulness and limits of a geographic perspective in dialectology: Arabic and Berber examples
}

\begin{abstract}
Spoken Arabic and Berber show great variety in their pronunciation, as evidenced by dialectology studies. Some researchers have attempted to illustrate this variety using maps of the data collected. In this article, my goal will be to commend their work, but also to highlight the difficulties which arise when a purely geographic perspective is adopted. The choice of discriminant in relation to the possible variation mechanisms will also be broached, as, for the languages under study, spatial dissemination only partially explains the linguistic differences and similarities.

Keywords: Arabic; Berber; linguistique geography; sociolinguistic; historical dialectology; hierarchy of discrimants.
\end{abstract}

\section{Linguistic atlases}

It is only recently that dialectal variation has been mapped for Afro-asiatic. However, over the past few decades, a number of publications have changed this situation, particularly for Arabic. ${ }^{1}$ I will nonetheless begin with the Berber languages, where linguistic geography is as yet in its early stages.

\subsection{Berber varieties}

One of the first linguistic geography studies using maps was carried out by André Basset (1942). The study examined body part names and, even though all of the varieties studied (ranging from the Tiznit region to the south of Goulimine) were parts of Tachelhit, the boundaries were so variable from one map to another that each word seemed to have its own history. ${ }^{2}$ Basset concluded that this specific sedentary group spoke "dust varieties" ("une poussière de parlers"), an oft repeated phrase indicating the ephemeral, transient nature of these language varieties. Basset further believed that such a situation was the consequence

1 Arabic and Berber belong to the same Afro-asiatic phylum, but Berber is a linguistic family unto itself while Arabic belongs to the Semitic language family.

2 At times an Arabic word replaces a Berber one, at others two Berber words compete with each other. 
of the intensity of local life and its primacy over more extended regional groupings, even though the phenomenon is not restricted to the southern Moroccan region.

Since Basset, other linguistic geography studies have confirmed this analysis; it was not until 2007 however that the first atlas of a Berber variety was published.

Lafkioui's work, devoted to the Rif region in northern Morocco, is based on extensive fieldwork. Taking speakers from 22 tribes, she carried out, directed and semi-directed linguistic enquiries in 141 different areas. The results are brought together and synthesized in 356 maps: 106 bearing on phonetic and phonological issues; 188 (107 to 294) on morphological and syntactic issues; and lastly 62 maps (295 to 356) on the lexicon.

Below are three maps, each exemplifying a different field.

- Map 62 explores the velar consonant $/ \mathrm{kk} /$. Four distinct pronunciations were found for /tikkit/ 'louse': [țiššit] (primary pronunciation), [țičit] (2 locations in the west), [tičit + tiššit] (1 location in the west - transition area), and lastly [tikkit] (15 locations in the far west).

- Map 187 is devoted to the proximal demonstrative pronoun in the M pl. ('these'). Fourteen variants were found, e.g. yina, ina, yiya, wida, widi, widda, iyya, wihi...

- Map 356 on the other hand only shows two variants for the verb 'need', spread over two relatively balanced groups: (east) [ḥwažž] vs. (west) [ḥdažž].

These maps give an idea of the type of variation to be found in the Rif region. Tribally speaking, there are three sub-regions (including the Ktama region in the west and the Iznassen region in the east), however the isogloss maps show that from one map to the next the variation is much greater. The general impression is once again that of several varieties in imbrication, without the cohesion of Rif being upset however. ${ }^{3}$

\subsection{In the Arabic varieties}

Linguistic geography maps have been drawn up for many of the Arab world's regions. In a handbook on Arabic linguistic geography published in 2005, Behnstedt and Woidich draw up a complete inventory of these studies (p. 4-7). Being themselves authors of several atlases, they were in a good position to provide a comprehensive list. I will only dwell on the most important references here.

An initial set of 42 maps was published by Bergsträsser in 1915. In this work, the author maps out Syria and Palestine based on only 62 fieldwork locations. The results have been called into question by several renowned dialectologists. Cantineau (1960[1955]) for example criticized the distance between fieldwork locations and the methodology used, as Bergsträsser based his enquiries on one text only. To produce the 60 maps in his own study

3 It should be noted that the Iznassen variety does not, strictly speaking, belong to the Rif dialect group. 
on the Arabic varieties of Hōrân, published in 1946, Cantineau chose to cover a much smaller area, but took more locations into account, at shorter distances from each other.

The most widely respected cartographic work on Arabic varieties is Behnstedt and Woidich's study of Egypt. The first two volumes were published in 1985. The second volume contains 560 maps on 438 subjects. The first volume contains the commentary and interpretation of the maps, which are based on 800 fieldwork locations. Two other volumes were published in 1987 and 1988, consisting of texts documenting the Nile and oasis dialects, which had been very little studied hitherto.

Behnstedt is considered the greatest specialist on the linguistic geography and cartography of the Arab world. Following his fieldwork in Egypt he moved on to do fieldwork in several other Arabic speaking regions.

No later than 1985, Behnstedt brought out an atlas of the North-Yemen dialects. With 165 fieldwork locations, the atlas contains 169 annotated maps, data which lead the author to conclude that the region houses eleven different dialect varieties, spoken in clearly distinct territories. This work was added to in 1987 , by the publication of a grammar on the three Arabic varieties spoken in the northern Sa $\mathrm{a}^{\Upsilon}$ dah region. The 27 maps illustrating the grammar seem to indicate that isoglosses do not always follow dialect borders and that in some cases there are more than three language varieties (e.g. there are ten variants for the place adverb 'here' as evidenced by map 26, p. 126: hunāk, hināk, hinayyāk, hinayla, hināl, hinēl, țamm, tallì, halah, han).

In the 1990s, following a co-production with Arnold (1993) on the Arabic-Aramaic relations in the Syrian province Qalamûn, Behnstedt edited an atlas of Syria (1997) based on 500 fieldwork locations and 517 questionnaire items. ${ }^{4}$

In 1998, Arnold published a grammar of the Arabic variety spoken in the Antioch region, a multicultural Turkish province where several Arabic speaking groups reside, furnishing a wide variety of life styles, traditions and religions. More than a third of the volume is composed of 59 maps and their annotations. 57 features, mainly morphological, are mapped. Among other works which include linguistic geographical data, are De Jong (2000) on the northern border of the Sinai, which includes 73 maps, and several collective works and journals which mention atlas work in progress.

One such work is a planned linguistic atlas of Tunisia (see e.g. Baccouche \& Mejri (eds) 2004). Another is the planned atlas of Morocco, for which Behnstedt among others began fieldwork in the north western region in 2000 (see Behnstedt 2002, 2005, 2007).

In the last two articles mentioned above, Behnstedt looks more specifically at animal names and human body parts. These give an idea of his new research interests, circumscribed within a region where variation is particularly high. With Woidich, he has just published the first volume of a lexical atlas of the Arab world (Behnstedt \& Woidich 2011). They both had

4 A collection of texts to accompany the atlas was published in 2000 . 
occasion to present their ongoing work at the conference 'From Linguistic landscapes to Landscape Linguistics' held in Paris on the $28^{\text {th }}$ and $29^{\text {th }}$ of January, 2011.

\section{Spatial continuities and discontinuities}

For Arabic, linguistic atlases are increasingly numerous, and are devoted to regions with high levels of diversity - an indisputable progress for knowledge of the Arabic dialects. Maps based on scientific questionnaires not only render the borders between already known (or newly identified) dialect varieties more precisely, they also highlight the range of each specific trait, the limits of which are often much more erratic than expected.

In the atlases presented here however, linguistic cartography is usually a simple representation method. It is used to show variation spatially. This method remains highly limited, at least for atlases in book form, as they project reality onto just two dimensions. ${ }^{5}$

Moreover, these atlases display maps rather than interpreting them, according to the distinction established by Chambers \& Trudgill (1980: 29): "Display maps simply transfer the tabulated into a geographical perspective. Interpretive maps attempt to make a more general statement, by showing the distribution of predominant variants from region to region. [...] Interpretive maps are more frequently found in secondary studies which use the data of a dialect geography project as the primary source from which a specific topic is developed."

Indeed, maps produced within the framework of spatial linguistics allow an immediate distinction between majority and minority, or central and lateral areas. That being said, while such distinctions are very useful for discussion, they cannot be considered reliable evidence for analyzing the causes behind linguistic change nor its directionality. All the more so when the maps do not show the entire language (all dialect varieties), but only a sub-field (one region or country), often restricted to very closely related varieties. In order to validly reflect on the spatial distribution of a given linguistic form, it is often highly useful to have information on both the close and the more distant neighbors of the dialect variety under study.

I will return to this question below, but I would first like to highlight some non-spatial, or no specifically spatial, aspects of linguistic variation. These aspects very probably play a crucial role in dialect diversification, which could explain in part the non-negligible attention devoted to them in Behnstedt \& Woidich's (2005) work on linguistic geography where their explanatory objective is manifest - contrary to what is found in most atlases.

5 I am certain that digital atlases will provide new possibilities that are not (yet) present in the atlases discussed here. 


\subsection{Isotopies and sociolectal variation}

Most linguistic enquiry protocols aim for a certain representativeness. Parameters such as gender and age are regularly taken into account, often accompanied by socio-economic factors, e.g. schooling. When the goal is to establish an atlas, investigators also tend to choose consultants who were born in the area under study or who have had little contact with groups speaking another language variety. In attempting to grasp a synchronic state, linguists tend to prefer speakers who will reflect the language state handed down by past generations. There are nonetheless limits to the spatial distribution of variation. It usually appears better suited to traditional societies - especially rural sedentary groups - rather than to urban dwellers, where migration and social interactions tend to give rise to the coexistence of divergent forms within the general population. Therefore it is in research devoted to urban dialectology that personal parameters are of primary importance. Even though this facet of linguistic change is most readily noticeable in urban settings, this does not entail that it is not to be found in rural areas.

\subsubsection{Young vs. elderly people}

Linguistic change is often initiated by young people, especially the most radical of linguistic changes, that of no longer speaking a language. The fact that Zenaga is no longer spoken in Mauritania by adults (nor, obviously, by children) under 45 years of age bodes very ill for the survival of Berber in the country, and is a sufficient criterion for classifying the language among the 'severely endangered' language varieties.

Schooling is a decisive factor and tends to affect young people more than their elders. Therefore when certain varieties are described as being used by young people, these are often varieties which are borrowed from or influenced by the Standard Arabic they are taught at school. This seems to apply e.g. to the conditional system in Yafí (Yemen) where young people use ' $i \underline{\mathrm{d}} a$ alongside the more traditional particles (Vanhove 2002). When the language taught at school is Greek rather than Arabic, this appears to have just as much influence over the language varieties spoken by young people. This is borne out by a tendency to use the subjunctive instead of the indicative after the particle ámma 'when' borrowed from Greek (Roth 2003).

Causes for change cannot however be reduced to schooling nor to the languages taught at school. The dialectology literature shows various innovations among young people which do not indicate any convergence with Literary Arabic. Variation in the pronunciation of $q \hat{a} f$ in the Alep region shows that, especially among young people, there is a tendency to replace the traditional rendering /q/ by a (dialectal) glottal pronunciation $\%$. Map 13 published by Behnstedt \& Woidich (2005: 62) indicates variation in the pronunciation of young vs. elderly people in six fieldwork locations. This highlights how a prestigious variant spreads, independently of whether it conforms to Literary Arabic or not. 
Lastly one notes that young people have a higher tendency towards variation. Hagège (1973: 67) demonstrated that in the Chadic dialect Nala spoken by young people, they used a "mixed system" (free alternation between forms with or without the verbal prefix $b$-) which he considered evidence of the competing influence of two distinct varieties of Arabic (rather than the influence of Literary Arabic on the dialect in question).

\subsubsection{Men vs. women}

More and more studies are specifically devoted to linguistic differences between men and women (cf. the latest issue of Estudios de Dialectología Norteafricana y Andalusi), but of course this phenomenon has been observed for many years, mainly from a phonetic perspective, but also in the lexicon. As is often the case, other linguistic domains are seldom mentioned (cf. Rosenhouse 1998). ${ }^{6}$

At the beginning of the 20th century, for example, the speech of Jewish women in Algiers was characterized by a very lax pronunciation of the pharyngeal consonant $\delta /$ (Cohen 1912: 31). Laxness was also characteristic of the manner in which Cairene women pronounced the so-called emphatic pharyngeal consonants $\left(/ t^{\uparrow} \mathrm{d}^{\varsigma} \mathrm{s}^{\varsigma} \mathrm{z}^{\mathrm{s}}\right)$, pronouncing them rather as simple consonants [t d s z] (cf. Cohen 1973a: 220).

Women are often said to be more conservative in their language varieties. In Djidjelli-ville (Algeria), Marçais (1956: 19) notes that the phoneme which men usually pronounced as a

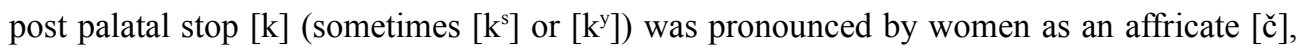
in keeping with rural pronunciation. He also noted (idem: 163), among other examples of convergence, the fact that both women and rural speakers used the lexeme $r a$ instead of šâf for the verb 'see' (the latter rendering being a borrowing). Moreover, in Muslim Tunis, it was noted that women maintained a diphthong in words such as bayt 'room' and mawt 'death' whereas in men's speech the vowel was not a diphthong (bït and mīt) (Cohen 1973a: 219).

While it is true that there is a certain tendency towards conservatism among women, other factors such as age and schooling must be taken into account, as evidenced by the fact that young women in Tunis also tend to disprefer diphthongs. ${ }^{7}$ The specific traits in the speech of elderly women which was highly visible in the past (on their prosody, see the case of elderly women in Șan'ā in Naïm-Sanbar 1994), was very distinct from the speech of young women who, rather than being noticeable for their conservatism are instead remarkable for their tendency to adopt innovations. Abu-Haidar, noting this trait among young Iraqi women in Baghdad (1988, 1989), drew a parallel with the fact that, generally speaking, women "are more sensitive than men to the prestige pattern" (Labov 1972: 243). Haeri (1996) shows that the tendency towards palatalization is more marked among women than men in Cairo, thereby illustrating yet another aspect of the sexual divide identified by Labov (idem: 304):

6 Some studies, e.g. Henkin $(2000,2010)$ do show that there are marked differences in narrative styles between men and women.

7 "It appears that school, which is now open to both boys and girls, moves the latter to exclude 'feminine' traits from their speech, so that the former distinction is present only in the speech of unschooled girls, giving it new significance" (Cohen idem: 219). 
"the sexual differentiation of speakers is therefore not a product of physical differences alone, or of different amounts of referential information supplied by speakers, but rather an expressive posture which is socially more appropriate for one sex or the other."

\subsubsection{Differences in education and social backgrounds}

The very numerous studies on 'median' Arabic, i.e. Arabic speech showing an intermediate stage between standard and dialectal Arabic, quite consistently point out the role played by school in the appearance or spread of this type of mixed Arabic. While in countries such as Mauritania, the media and various political movements seem to have played a significant role, in the Middle East schooling has been such a determining factor that all authors agree on calling this variety "Educated Spoken Arabic". However, the influence of social backgrounds extends beyond this type of speech.

Linguists studying Arabic dialects have also highlighted the importance of more or less extensive schooling in linguistic change (see fn 7), however it is in variationist linguistic studies that this type of influence is measured most precisely. In her study on pharyngealization in Cairo, Haeri notes that "weak palatalization, which seems to have entered the phonology of Cairene Arabic before strong palatalization, is an innovation of upper middle class women" (idem: 108).

Al Wer studies "the use of the innovative feature [t] (corresponding to Classical Arabic [ ]) among the female speakers, grouped according to three educational categories". She shows a "correlation between the speakers' level of education and their use of the innovative feature, with the highest educational group, the university- or college-educated speakers, showing the most advanced usage of [t] while, in this respect, the lowest educational group, the illiterate speakers or those with minimal education, lag considerably behind" (2002: 48).

As with the situation observed by Al Wer, Cohen notes that "in the provincial towns of Sult, Ajloun, and Kerak in Jordan, it is among women belonging to the highest spheres of Jewish Tunis society (up until the 1950s) that the least classical pronunciations are to be found. These women (particularly when they are in contact with the French) no longer make any distinction between the so-called emphatic consonants $\left(/ t^{\uparrow} d^{\varsigma} s^{\varsigma} z^{\varsigma} /\right)$, whereas in lowlier spheres, women's speech is characterized by 'excessive emphasis' and velarization which is even more extensive than among men." (Cohen 1973a: 221).

When several pronunciations compete, it is usually the forms closest to Literary Arabic which are preferred by those highest on the social scale. This is shown by Abu-Haidar (1987) for the Muslim dialect spoken in Baghdad: among illiterates or people with little schooling, the forms they use (/brīž/, /žirīb/and, with metathesis, /șigid/) are more locally contained and more distinct from Classical Arabic than among the more schooled (/barq/, /qarīb/and /șidq/) — respectively 'lightening', 'near' and 'truth'.

\subsubsection{Differences in religion}


In various parts of the Arab world one finds (or rather found, up until the end of the 19th century) coexistent groups with different religions. In many cases, the groups were recognizable by their manner of speaking. The fact that such differences arise, and more importantly, that they are retained, is of course not unrelated to a lack of interaction between members of different communities. However, especially in urban settings, they cannot be explained by a complete lack of contact, nor by the continuation of absolute spatial segregation.

In northern Africa, the linguistic specificities noted are generally those which distinguish the speech of Jewish populations from that of Muslims. Thus Cohen comments on the accent particular to the Jewish inhabitants of Algiers at the beginning of the 20th century (1912: 172 , note 1): "adding [...] the pronunciation of $?$ for $q$ and $\check{s}$ for $s$, the very strong imala and the high pitch accent with an indefinite lengthening of the final syllables are very characteristic of the Jewish Algerian accent".

The Jewish dialect spoken in Fez is a variety which was studied at approximately the same time (Brunot 1936). The same glottalized version ? for $q$ is found, as well as the same tendency to merge sibilants and post-alveolar affricates, except that in this variety it is the sibilants which are retained (and which are realized $/ s^{\varsigma} /$ and $/ z^{\varsigma} /$ in an emphatic context).

Jewish speech varieties share various resemblances; however no feature is shared by all, even within northern Africa, nor is any feature exclusive to them (cf. Cohen 1985). The recent study by Heath (2002), which carries out an extensive comparison of all Moroccan varieties, both Muslim and Jewish, ${ }^{8}$ does not belie this affirmation and even shows that in some Moroccan Jewish varieties the sibilant/post alveolar affricate distinction is maintained. Heath highlights the trends which dominate each of the religious communities; it is extremely rare however that for the highly numerous features he analyzes (especially in the lexicon) the 'schematic' maps be identical.

There was also a distinction between the Jewish and Muslim varieties in the Middle East. In Cairo for example, the $1^{\text {st }}$ person singular imperfect prefix was $n$ - in the Jewish varieties (as it was in the North African varieties) and ?- in the Muslim varieties (as in the other oriental dialects).

The most spectacular case however is described by Blanc in a 1964 study. It concerns the city of Baghdad where the local populations were divided into three religious groups with as many distinct Arabic dialect groups. Of the highly numerous differences noted, only a few are mentioned in the table below (Table 1).

On the whole, the Christian and Jewish dialects are more similar to each other than to the Muslim dialect, as indicated by the pronunciations given in the table's first line: pronunciation of the $q \hat{a} f(g$ vs. $q), k \hat{a} f(\check{c}$ vs. $k)$ and $r \hat{a}^{\gamma}(r$ vs. $\dot{g})$. However, it was very easy to

8 Concerning the Jewish dialects, he bases his analysis on the works of Lévy whose thèse d'Etat, defended in 1990 , was published in 2009. 
find examples illustrating other groupings, either a trait shared by the Muslim and Christian dialects (huwwa or long $\bar{o}$ and $\bar{e}$ ) or one shared by the Muslim and Jewish dialects (retention of interdentals).

\begin{tabular}{|c|c|c|c|}
\hline $\begin{array}{l}\text { Standard } \\
\text { Arabic }\end{array}$ & Muslims & Christians & Jews \\
\hline$q \hat{a} f ; k \hat{a} f ; r \hat{a}^{?}$ & $g ; \check{c} ; r$ & $q ; k ; \dot{g}$ & $q ; k ; \dot{g}$ \\
\hline sg. pers. pron. & $1^{\text {st }} \bar{a} n i ; 3^{\text {rd }} h u w w a$ & $1^{\mathrm{st}} \bar{a} n a ; 3^{\mathrm{rd}} h u w w a$ & $1^{\text {st }} \bar{a} n a ; 3^{\text {rd }} h u w w i$ \\
\hline interdentals & retention & disappearance & retention \\
\hline diphthongs & $\bar{o}$ and $\bar{e}$ & $\bar{o}$ and $\bar{e}$ & $\bar{u}$ and $\bar{l}$ \\
\hline
\end{tabular}

Table 1: Communal Dialects in Baghdad (following Blanc).

Although the situation in Baghdad is unusual, it is not the only example of dialects and communities sharing the same borders. In Iraq, traces of Jewish and Christian dialects remain, and were highly numerous until very recently. In other regions, all the communities are Muslims, but practice different rites. Above and beyond the case of the Druze, the Sunni and Shia dialects show the greatest differences. This is a well known situation, especially in the east of the Arab Peninsula.

In Bahrayn, for example, up until the 1970s two communities lived in clear separation. The first, called Baḥārna, are Shia Arabs and live in Manāma and approximately 60 villages. The others, called 'Arabs' are Sunni and mostly live in Muḥarraq and a few coastal towns. Holes (2006) describes both varieties - specifying that it is the speech of unschooled people. The main dialects are distinct in their pronunciation of the phonemes $/ \check{z} /$ and $/ \theta /$ (Table 2). On other points however the Baḥārna show additional distinctions.

\begin{tabular}{|c|c|c|c|}
\hline Standard Arabic & Arabs (Sunni) & Bahārna A & Baḥārna B \\
\hline$\check{z}$ & $y$ & $\check{z}$ & $y$ \\
$\boldsymbol{\theta}$ & $\theta$ & $f$ & $f$ \\
\hline
\end{tabular}

Table 2: Baḥrayn (following Holes 1986)

Holes $(1980,1986)$ further shows that although the two communities still tend to occupy separate neighborhoods in cities such as Manāma, significant variation can be seen, under the compounded influence of more prestigious varieties (both Standard Arabic and the Sunni 
dialect). Thus a single phoneme may be pronounced in several different ways, not only depending on the speaker's background and schooling, but also depending on the word itself, or on the context.

Dialectal variation consists of sociolectal variation, and even more importantly of idiolectal variation. However, even though one can show several variants on a single map, ${ }^{9}$ this is not necessarily what is done in atlases. However, for the representation to be as clear as possible, it is usually better to have a specific type of map, accounting for the people's history and the social and historic factors which led to the changes found.

\subsection{Heterotopy and inherited linguistic features}

Contrary to the phenomena mentioned above, where variation typically follows a continuum, I would now like to draw attention to similarities which may be found in non contiguous areas, at times very far apart. These similarities may be due to various kinds of historical events which, in part, are well known.

\subsubsection{Regional migrations}

Historical accounts do not always recount population movements and, when they do, the information is not always directly relevant for dialectologists. It does happen however, and not infrequently, that crossing historical and linguistic data can shed a great deal of light.

Cantineau for example, in his linguistic enquiries carried out in southern Syria, noted that the Ḥōrânese mountain Drûz variety was both different from the surrounding dialects and similar to speech varieties spoken by sedentary Syrian-Lebanese-Palestinian populations farther afield. Before illustrating this, he explains the situation historically, specifying that at the end of the $17^{\text {th }}$ century the Drûz began their emigration from Lebanon to the Hōorânese mountains. ${ }^{10}$

In the mid $20^{\text {th }}$ century, the Ḥōrân Drûz had retained features characteristic of the southern Lebanese region whence they had come (retention of interdental consonants and diphthongs, a sibilant - non affricated - pronunciation of the djîm, etc.). Moreover, they do not seem to have been influenced by their neighbor's speech varieties, not even by the tafhîm (emphatic articulation) of their labials even though this seems to have spread everywhere else in the region. Their religious specificities certainly played an important role in their linguistic conservatism; the $19^{\text {th }}$ century emigrations also undoubtedly contributed. ${ }^{11}$

9 See for example Arnold's (1997) maps illustrating his study of the city of Antakya where he shows the variants of the four sedentary communities living there; usually one variant per community.

10 "Vers 1685, sous l'émirat d'Aḥmad, dernier émir de la famille des Ma ân, un certain nombre de Drûz émigrent vers le Ḥ̄ôrân, sous la conduite de Yalam ed-Dîn eben Ma ân, qui leur laissa comme gouverneur Hamdân elHamdân ; celui-ci établit son siège d'abord à Nežrân, à la limite sud du Ležâ, puis à Swêda" (Cantineau 1938a: 158).

11 Other events (for example resistance to Egyptian conscription in 1837-1838) led to an increase in the Drûz community's numbers, to such an extent that just before WW2 they accounted for $7 / 8^{\text {th }}$ of the mountain's 
Regional migrations have always existed, however it is often more difficult to interpret the effects this has on many language varieties than for the Druze. In fact, the language variety spoken by a given emigrant group tends to become more and more distinct from the language's other varieties over time, especially when it is in contact with a non Semitic language. Moreover, the variety spoken by non-emigrant groups also changes over time, making it very difficult to tell apart the origins of specific changes, especially when exhaustive data is lacking.

It is well attested for example that the existence of an Arabic variety spoken in Kormakiti, in Cyprus, is linked to the settlement of a Maronite community there. According to Roth, some authors consider that the first migrants arrived in the $7^{\text {th }}$ century, well before the Crusades. ${ }^{12}$ Linguists specialized in Cypriot Arabic have noted this dialect's numerous specificities, as well as the fact that the dialect may soon disappear due to the ever increasing use of Greek. These specialists have attempted to situate Cypriot Arabic within Middle-Eastern Arabic dialects, although, depending on the author, emphasis may be either on its similarities with Lebanese varieties (Roth ibid.: 93), or on its double ancestry, placing it within a much larger dialect area, stretching from northern Syria to Anatolia (Borg 2004: 24 and sq.).

Comparable questions arise for Maltese Arabic's relation to Tunisian, and even for the relation between the East African Creole Nubi and Sudanese (Heine 1982, Owens 1985). Nonetheless, knowledge of the historical facts can also shed light on more specific phenomena, such as the loss of interdental consonants in some North African communities; not only in Tunisia (Mahdia, Jewish Tunis), but also in Algeria, Morocco and Malta (which came under Arab influence through travelers from Mahdia as early as the $9^{\text {th }}-10^{\text {th }}$ century). These are mostly urban dialects influenced by the prestigious Kairouan variety: the city's inhabitants contributed to the feature's spread when they fled the city following the defeat of the Aghlabids at the beginning of the $10^{\text {th }}$ century (cf. Marçais \& Guiga 1925: XXII-XXIII, Cohen 1973b: 64, Caubet 2004: 64-65).

\subsubsection{Bedouin varieties}

In Northern Africa, the Kairouanese varieties belong to the group of so-called "pre-Hilalian" varieties, as opposed to the Bedouin type varieties which developed in North Africa from the $11^{\text {th }}$ century. These varieties took root following the arrival of various nomadic tribes, especially the Banū Hilāl and the Banū Sulaym tribes from the Arab Peninsula and Syria, and following a sojourn in Egypt (Marçais 1961: 186).

From this perspective, one could consider that this is a migratory phenomenon, as previously suggested. It is unique, however, that this variety was disseminated, not only throughout Northern Africa, but also throughout the entire Arab speaking world. Indeed, in the Middle East, phenomena similar to what is found in the Hilalian varieties are attested.

inhabitants.

12 However, "la plus forte vague d'immigration maronite en Chypre se situe à la fin du XII ${ }^{\mathrm{e}}$ siècle, lorsque Guy de Lusignan eut acquis l'île, en 1192, et qu'il fit appel aux Chrétiens des régions limitrophes, Francs et Chrétiens orientaux, dont les Maronites, pour coloniser son propre royaume" (Roth 1979: XI). 
For example, the Šāwi Bedouin dialect, studied by Cantineau (1936-1937) is spoken throughout the area stretching from the Alep Fertile Crescent to the north-west to the Persian Gulf in the south-east. Procházka (2003) shows that the Urfa variety, spoken in southern Turkey, belonged to the same dialect continuum, even though, in the region, it was spoken by populations which were sedentary at the time.

Historical factors, important as they are, should not be the only ones taken into account to explain the similarities and differences which crisscross Arabic dialectal geography. Data which are structured, or at least anchored in some "hard" temporality, must also be taken into consideration. Lifestyles, e.g. the opposition nomadic/sedentary dear to Ibn Khaldūn, through the regularities which they appear to be associated with, shed light on some of the more noteworthy convergences/divergences.

Socio-economic factors must obviously be taken into account given that all varieties spoken by nomads appear to belong to the Bedouin type. It must nonetheless be specified that a similar set of features may be found among sedentary populations, either because they were previously nomads (e.g. the above mentioned Urfa), or because the earlier urban variety was so heavily affected by nomadic influences as to have acquired a substantial set of such features. The Tripoli dialect in Libya is a well known case of an urban variety "buried" underneath a nomad layer, being as a result an essentially mixed or "hybrid" variety (cf. Pereira 2010: 499). The same is true for the Muslim varieties in Baghdad which attest to the influence of the Bedouin linguistic model, whereas the Christian and Jewish varieties tend to perpetuate the norms which were current before the nomads' arrival (cf. Blanc op. cit.).

The most highly visible feature shared by all Bedouin type varieties is the voiced articulation of $q \hat{a} f([\mathrm{~g}])$. This is a feature which is found from the Algerian Sahara varieties to the Mauritanian Hassāniyya variety, from the Baghdad Muslim varieties to the Bahrayn Sunni Arab varieties. While the unvoiced articulation of qâf may pre-date the voiced, it is nonetheless often to be found in Arabic varieties which are considered innovative. Such varieties are mostly spoken by sedentary populations, usually in urban settings, but in rural ones as well. It is also worth noting that the unvoiced articulation may differ in its place and mode of articulation: $[\mathrm{q}],\left[\mathrm{k}^{2}\right],[\mathrm{k}]$ or even [ [ ]

This feature aside, there is a certain family resemblance between the various Bedouin type varieties, but which is very difficult to qualify as it is mostly due to conservative traits. This means that they can only be grasped negatively, by opposition to the features observed in most sedentary varieties (cf. Taine-Cheikh 2002).

Some features which may be considered characteristic of the nomad varieties are the retention of interdental consonants (even though these are to be found elsewhere); the more marked retention of gender distinctions in pronouns and verbal conjugations; the retention of synthetic constructions, e.g. for noun determiners; the highly productive use of verbal and nominal derivations. 
In contrast, the sedentary varieties, especially among elderly urban populations, are generally characterized not only by the voiced pronunciation of $q \hat{a} f$, but also by various innovative trends: the tendency to drop interdental consonants (which are conflated with dentals); a tendency to develop one or several imperfective verbal particles; a tendency to use discontinuous verbal negation; a tendency to reduce the productivity and diversity of derivation.

\subsubsection{Some surprising resemblances}

Comparative dialectology constantly seeks similarities. These can belong to a variety of fields and are by nature highly diverse. Ferguson (1959) for example listed a number of features (phonetic, morphological, lexical...) which he believed characterized all urban Arabic dialects spoken outside the Arabian Peninsula. This was his way of attempting to prove that these varieties stemmed from a Koine, which would have evolved in military settlements during the expansion of Islam.

Beside the fact that the Bedouin varieties differ in the extent of their inclusion of these features (cf. Taine-Cheikh 1991: 1537-38), Ferguson's analysis is first and foremost of little use because, as shown by Cohen (1970[1962]), the features chosen are much too broad. Evolutions such as the invariability of comparatives or relativizers can be explained through universal trends, therefore it is impossible to consider that they indicate shared origins or a contact situation.

When one lexeme is replaced by another, as in the case of "see" where the root * $r a^{\text {? }} a$ tends to disappear in favor of $s \bar{a} \bar{f}$, there is every reason to attempt to discover why and how such a change took place. ${ }^{13}$

In other cases, e.g. $\dot{g}$ ayn being articulated as a stop [q], the evolution $\dot{g}>q$ should not necessarily be ascribed to a shared origin, even though this phenomenon is found in several Bedouin varieties, both in the Middle East and in North Africa. ${ }^{14}$ It could very well be a case of "empty slot" phenomenon, as analyzed by Martinet (1955: 103). Indeed, such an evolution seems all the more doubtful in these sedentary varieties as this slot is (or was, originally) occupied by the representative of $q \hat{a} f$.

On several occasions I have noted quite remarkable circumscribed resemblances between Mauritanian Hassāniyya and other dialects. Although such similarities could be due to chance or parallel developments, they could also signify a more or less diffuse historical kinship.

a) While most North African dialects show relative incompatibility in strings of sibilants, this always concerns specific strings. I have noted (Taine-Cheikh 1984) that sequences of

13 Here, Cohen's arguments show that, contrary to Ferguson's hypothesis, the change was certainly spread by the Bedouin varieties.

14 Cf. Rosenhouse (2006: 260) and on North Africa Marçais (1975: 389), Taine-Cheikh (1991: 1533). 
sibilants are processed similarly in Hassaniyya and in the Marazig Bedouin variety (southern Tunisia):

$s / z-\check{z}>s / z-z ; \check{z}-z>z-z ; \check{s}-s>s-s$.

b) It is not rare for the verb gām "get up" be grammaticalized either as an inceptive, with the meaning "begin", or as a discourse particle emphasizing a chain in the sequence of events (with the more or less syntactic expletive meaning "then"). On the contrary, in this second use, replacing gām by a verb meaning "take" is highly exceptional and therefore surprising to find in both Hassaniyya and in Bedouin varieties in northern Syria (cf. Taine-Cheikh 2011).

c) Procházka (2008: 211-2), in his study on prepositions, restricts the uses of ' $\bar{a} g \partial b$ "after" to a set of Middle-Eastern varieties: in most Mesopotamian dialects, in the Arabian Peninsula and in the Transjordan Bedouin dialects (in competition with $b a^{\varsigma} d a$ ), whereas, in fact, ' $\bar{a} g a b$ is used in an identical manner in Hassaniyya (cf. Taine-Cheikh, forthcoming).

\subsection{Linguistic borders, national borders}

While from an essentially linguistic geography perspective, similarities observed in geographically distant locations can remain unexplained, apparent situations of spatial continuity can make it difficult to delineate linguistic areas. A few lines will suffice to make my meaning clear.

\subsubsection{Isolated isoglosses}

Isolated isoglosses are highly frequent and are not necessarily meaningful. Isogloss maps can show a multitude of crossing lines corresponding to a multitude of varieties: this is a particularly common phenomenon in areas where the populations have long been sedentary (cf. Dialectology p. 108). In such a case, one may choose a specific isogloss and study the more minute variations, using it to detail the various stages in a change's dissemination. This is what e.g. Lafkioui (2009) does for $r$ which, in Rifain, can be either vowelized or pronounced $l$.

Taking one specific isogloss into consideration can qualify large areas, for example: in the $1^{\text {st }}$ person imperfective, eastern varieties mark the plural by the prefix $n$ - (sg. aktib vs. pl. $n$ əktib) while western varieties mark it by the suffix $-u$ (sg. nəktib vs. pl. nəktib-u).

In a very different, more radical context, an isogloss may also serve as an identity marker. In this case, the salient feature is often part of a set of other differential features, but can become symptomatic of the separation between two linguistic communities. Such a phenomenon, called shibboleth in the literature, was pointed out by Cohen (1973b: 66) in Alep where the lexeme for "bull" was pronounced either $\underline{t} a w r$ or $\underline{\mathrm{t}} \hat{\mathrm{r}} \mathrm{r}$ depending on whether the speaker was Christian or Muslim. 
More recently, when it was a question of holding a referendum on the area of the Western Sahara which had formerly been colonized by Spain, the southern populations suggested limiting the right to vote to those who, like them, pronounced the word for "jackal" with an interdental consonant (i.e. $\underline{\mathbf{d}} \bar{i} b$ - and not $d \bar{\imath} b$ ). This does not mean that the retention of [d] $]$ was the only trait specific to Hassāniyya speakers, merely that it was sufficient to establish a distinction between Hassāniyya and the other Arabic varieties spoken in Morocco.

\subsubsection{Isogloss bundles}

In the case of Hassāniyya, retention of interdental consonants and voiced qâf are just two characteristics among others shared by all of the variety's speakers. There are many other more specific features - for example the use of the invariable morpheme lāhi to express the future or the affix $u$ - to form the passive voice of factitive derivatives (e.g. $u \mathrm{~d} a a^{\Uparrow} a v$ "he has been weakened", passive of $\mathrm{d} a{ }^{\Upsilon \Upsilon} a v$ "he weakened") [cf. Taine-Cheikh 2004 and 1983]. Hassāniyya shows very little variation, except on very specific points such as the switch $\dot{g}>$ $q$ which only concerns some Hassanophones (in the west and south-west the switch only occurs when $\dot{g}$ is a geminate: $\dot{g} \dot{g}>q q)$ or the voicing of $/ \mathrm{f} /([\mathrm{v}])$ - which is unusual in Arabic but very widespread in Hassāniyya, with the exception of the Timbuktu region (cf. Heath 2003: 8). That being said, this Arabic variety is spoken throughout an immense territory which spans far beyond the borders of Mauritania: not only to the east, but also to the north (to southern Morocco, near Guelmime) and to the north-east (to the Algerian Tindouf region).

It is thus possible to state that Hassaniyya is Mauritanian Arabic, given that there is true dialectal unity among all of the country's Arabic speaking populations, even though this could mislead people into thinking that the dialectal and national borders coincide. Work conducted by Heath in Mali indeed confirms the impression left by previous works, namely that Timbuktu Hassāniyya differs very little from Mauritanian Hassāniyya (or from Guelmime Hassāniyya for that matter, cf. Taine-Cheikh 1999a).

Hassāniyya, as a specific language variety extending beyond a single country, is a rather isolated case. More often, one hears expressions such as "Moroccan Arabic", "Libyan Arabic" or "Egyptian Arabic", giving the impression that the linguistic situation is much more uniform than it is in truth. Simplifying reality is equivalent to considering that the dominant variety (spoken in the capital/on the television/by the elite) has already eclipsed the other varieties, or that the situation gave rise to a koine variety. In fact, dialectology shows that differences remain very widespread.

With some exceptions such as Maltese - which is the only dialectal Arabic variety (or "neo-Arabic") to have acquired the status of written and official language - national borders are therefore not necessarily the most fitting framework for linguistic studies.

Some studies, however, going beyond idiolects or varieties specific to a given community, have attempted to extrapolate elements which could be common to larger geographical 
areas. Research carried out from this perspective has made it possible to identify various linguistic areas, which very often transcend national borders. This is the case of the varieties spoken by nomadic Tunisian populations in the Gabès region which Cantineau (1938b) also finds in the Constantine region, and which he labels as constituting the "E group" of Algerian varieties.

One of the largest linguistic areas to have been circumscribed is the Chadic-Sudanese area (Kaye 1946). The varieties of Arabic spoken in this zone are highly varied, for example in their status and uses, e.g. mother tongue vs. vehicular language, but nonetheless show characteristics which make it possible to set this specific dialect group apart from all others, for example: voiced $q \hat{a} f$, absence of interdental consonants, the quasi generalized disjunction of the syllabic group $\mathrm{C}_{1} \mathrm{vC}_{2} \mathrm{C}_{3}$, use of the verbal prefix $b$ - before the imperfect and the relative pronoun al. However, in order to characterize the linguistic area, it would have been more useful to use "weighted discriminants", retaining only the most marked features, as does Roth in a 1994 article.

\section{The choice of discriminants and their hierarchy}

One of dialectal geography's weaknesses lies in the difficulty of establishing a hierarchy among isoglosses (Chambers \& Trudgill, op.cit.: 112).

Dialectometrics offers an alternative which consists not of making such a classification easier, but rather of taking into account all differences in order to establish the distance separating linguistic varieties. Some linguists have applied automatic variation processing methods to Berber, arriving at interesting results for two highly varied regions, namely Rif (Lafkioui 2009) and Kabylie (Naït-Zerrad 2005 and 2009).

To the best of my knowledge, no attempt has been made so far to apply this method to an entire linguistic area (be it Arabic or Berber). The completion of Behnstedt and Woidich's lexical atlas of the Arab world (of which the first volume has just been published), will make it possible to carry out lexical dialectometric analyses, based on the semantic fields studied. However, it is uncertain whether it would be judicious to refrain from establishing a hierarchy in the variation found in such culturally and linguistically distinct fields as "fish" (where Arab dialects show a remarkably clear two-way split) and "sock" (a notion foreign to many Arabic speakers, so that if for some reason they wish to refer to it, they usually use a recent borrowing from some other language).

In absolute terms, the granularity which should be applied to lexical isoglosses is the same as for other types of variation. Even if all differences were taken into account (which would be difficult both for Arabic and for Berber), establishing a hierarchy among them is a question of the utmost importance. One of the answers devised by the French dialectology 
school initiated by Marcel Cohen and further developed by David Cohen was the creation of specialized questionnaires.

\subsection{Linguistic and sociolinguistic questionnaires}

During the first Congrès d'études des cultures méditerranéennes d'influence arabo-berbère, David Cohen raised the question of dialect distribution as it existed at the time and of how to interpret variation between dialects. In his answers, he emphasized the following paradox (1973b: 65): "Quel est pour nous l'intérêt de la géographie dialectale? Paradoxalement en apparence, il est surtout d'ordre historique ou sociologique. Quand nous fixons un fait linguistique quelconque et que nous le suivons le long d'une ligne isoglosse, le renseignement que nous prétendons en tirer est, au moins en partie, d'ordre historique. Sauf les cas où se manifestent des convergences fortuites dans des évolutions indépendantes, l'existence de lignes isoglosses en faisceaux a une signification socio-historique. Elle peut constituer l'indication d'une parenté plus étroite entre des dialectes qui les partagent qu'entre ceux qu'elles ne traversent pas." 15

Thus Cohen declared himself to be entirely in favor of an interdisciplinary and comparative approach, where linguistic analyses take into account sociolinguistic usage. To reach his goal, which he announced in the title of his presentation ("Pour un atlas linguistique et sociolinguistique de l'arabe"), his project was to supplement the analysis of internal structural data by the study of contacts and their consequences on linguistic usage. It was therefore because of the need for gathering a specific type of linguistic data that the issue of linguistic enquiry questionnaires was raised.

In the framework of a projected linguistic atlas of Arabic in Africa, Cohen advised using three complementary questionnaires.

i) The Linguistic enquiry questionnaire by Marcel Cohen, a rather general questionnaire, designed to collect the data necessary for basic linguistic descriptions.

ii) The second was more specific and was intended for comparative and historical purposes ("Plus de cent traits 'nodaux', reconnus comme différenciateurs à travers l'analyse de toutes les descriptions réalisées jusqu'ici, constituent des 'glosses' dont on compte établir la distribution à travers l'Afrique arabophone"16) (Cohen 1973b: 69).

iii) The third was purely lexical (approximately 200 items) and was designed for gathering basic vocabulary.

15 "For us, of what use is dialectal geography? Ironically, on the surface, the reasons are mainly historical and sociological. When you choose a linguistic item and follow its isogloss line, the type of information this can provide is, at least in part, historical. With the exception of the coincidental convergence of independent developments, the existence of a bundle of isogloss lines has socio-historical meaning. It can indicate closer kinship between the dialects crossed by the lines than between those which are not".

16 'Over one hundred feature 'nodes' deemed discriminant through the analysis of all available descriptions, constitute 'glosses' for which we intend to establish the distribution in all of Arabic speaking Africa”. 
The novelty of this approach resided not so much in the questionnaires as in the inventory of the feature "nodes", which David Cohen later proposed calling "macro-discriminant features" (Cohen \& Caubet 2000: 3). This questionnaire, of great socio-historical value, was created in the 1970s by David Cohen with help from Nada Tomiche and later Arlette Roth.

This questionnaire was designed to establish not only discriminant lexical or grammatical items but more importantly the macro-differential features which would reveal fundamental structural differences and transcend coincidental resemblances.

This entailed its use by well trained specialists, with solid grounding in Arabic linguistics: "Ce qui fait l'originalité de ce travail, c'est son approche comparatiste spécifique à la dialectologie arabe, mais aussi le type d'enquêteurs auxquels il s'adresse." (Cohen \& Caubet, ibid: 7$){ }^{17}$

The temporary version of the dialectology questionnaire as written by Cohen and his team is reproduced in Cohen \& Caubet (ibid: 7-23). As an illustration, some of the questions $(1,38$, 40, 41) are given below.

voCALISM 1) Syllable structure $\left[1^{\text {st }}\right.$ question out of 7]

1.1. Are there non-final open syllables containing short vowels?

1.2. Which short vowels can be found in non final open syllables?

C. In comparison with Classical Arabic, which vowels, depending on the syllable sequences, are deleted or retained?

Commentary on the question:

type *ba-ga-ra, *ka-tab, *da-ra-bat (for example, how do you say "a cow"; "my cow"; "your cow"; "your (pl.) cow"; "he wrote"; "she wrote"; "they wrote"; etc.)

type *li-sān $[\ldots]$

type $* k u-t u b[\ldots]$

\section{8) Expressing the future}

How is the future expressed? Is it conflated with the simple imperfect or does it entail the use of a particle? (For example ḥ $\bar{a}$ - in Egyptian, lāhi in Mauritanian, $t t a-$ in Cypriot Maronite Arabic, etc.).

40) Vocalic passive voice

Is there a vocalic passive voice marked by the nature of the thematic vowel? (For example in Mauritanian, active voice: baxxar, passive voice: ubaxxar; elsewhere one may find a distinction of the type qatal/qv̌t

41) Prefixed passive voice

Which prefixed derived forms are used to express the passive voice? (For example $t$-, $n$-, $t$ and $n$-, $l$-, etc.). How are the forms in $t$ - and in $n$ - distributed when they are in competition? If applicable, how are the prefixed passive voice and the vocalic passive voice distributed?

17 "The originality of this work resides in its comparative approach which is specific to Arabic dialectology, as well as in the type of field researchers who will use it." 
Several authors have proposed additions to this questionnaire, for example Caubet (2001) who retains the same perspective while furnishing a more precise list of questions for the study of North African varieties. Discriminants may nonetheless be used in other contexts, such as for comparing Maltese with Romance and Semitic languages (Comrie 2009). ${ }^{18}$ What is important here is to choose the most appropriate level of granularity, somewhere between a selection of discriminants valid for all the world's languages and all possible discriminants for Arabic.

\subsection{Some macro-discriminants}

In my own research, I have looked into several features which may be called "nodes" or "macro-discriminants" in David Cohen's terms:

a) Pronunciations of $q \hat{a} f$ and interdental consonants

b) The passive voice and the reflexive (in Arabic and Berber)

c) Causation and the causative (in Arabic and Berber)

d) The diminutive (in Arabic and Berber)

e) The comparative (in Arabic)

f) Negation (in Arabic and Berber)

g) Numerals (in Arabic and Berber)

h) The future (in Arabic and Berber)

etc.

The starting point for all of these studies is to be found in the specific traits featured by the Mauritanian Arabic (Hassāniyya) and Berber (Zénaga) varieties. The study of specific phenomena in either of these varieties naturally led to comparing the results with what is to be found elsewhere. In this manner, the fracture lines or, inversely, the convergence zones, grew progressively more precise, and made it possible to specify how Arabic and Mauritanian Berber fit in with the rest of their linguistic family.

Fundamentally speaking, this approach could lead to representations in the form of maps. However, maps I have drawn up to illustrate the pronunciation of qâf and interdental consonants as macro-discriminants (Taine-Cheikh 1999b) could be much harder to draw up for other features, especially when documentation is insufficient or the features highly complex. When studying a problem in great detail, one often realizes that a structure which seemed to be absent from a given variety is actually to be found in very specific contexts

18 Because Maltese is a Semitic language which has undergone considerable influence from Romance languages, one could expect it to be situated between Semitic and Romance, typologically speaking. Data from the World Atlas of Language Structures show that this is indeed the case, but that Maltese is generally closer to Semitic (represented in WALS by Egyptian) than to Romance (represented in WALS by Spanish). 
(for example in the case of borrowings in Zénaga, where numerals must be followed by a preposition) or under precise conditions (such as the first root $2, L, M, N$ or $R$ for -t-passives instead of $n$ - in Hassāniyya). This illustrates that taking an entire linguistic domain into consideration must not be carried out at the cost of sufficiently detailed analyses.

\section{Conclusion}

In some areas, linguistic change may happen mostly through close contact, giving the impression that certain innovative forms spread, wavelike, from village to village.

The explanatory power of this propagation mode certainly stems from history and how societies function. In Berber communities and perhaps even more so in Arab communities, the importance of geography seems largely outweighted by the importance of history. The differences between varieties spoken by Bedouins and by sedentary populations clearly show that one cannot make a simple distinction between East and West. Similarly, traits to be found in Mauritanian Arabic are sometimes sufficient to cast doubt on the widespread tendency to assimilate a peripheral geographic location with linguistic marginality (TaineCheikh 1991).

One may hope however that in the future combining the various perspectives will be made easier by the creation of linguistic atlases bearing on macro-discriminants, mapping out entire linguistic areas. This will most certainly show that paying close attention to details brings out the substantial diversity in the ways linguistic changes are propagated.

\section{Références bibliographiques}

Abu-Haidar, Farida (1987): The treatment of the reflexes of /q/ and /k/ in the Muslim dialect of Baghdad, in: Zeitschrift für Arabische Linguistik 17, 41-57.

Abu-Haidar, Farida (1988): Male/female linguistic variation in a Baghdad community, in A. K. Irvine, Robert B. Serjeant \& G. Rex Smith (eds.), A Miscellany of Middle Eastern Articles: in Memoriam Thomas Muir Johnstone, 1924-83. Harlow: Longman, 151-162.

Abu-Haidar, Farida (1989): Are Iraqi Women More Prestige Conscious Than Men? Sex Differentiation in Baghdadi Arabic, in: Language in Society 18, 471-481.

Al Wer, Enam (2002): Education as a Speaker Variable, in: Aleya Rouchdy (ed.), Language Contact and Language Conflict in Arabic. Variations on a Sociolinguistic Theme. London: Routledge Curzon, 41-53.

Arnold, Werner (1998): Die arabischen Dialekte Antiochiens. Wiesbaden: Harrassowitz.

Arnold, Werner \& Behnstedt, Peter (1993): Arabisch-Aramäische Sprachbeziehungen im Qalamûn (Syrien). Eine dialekgeographische Untersuchung mit einer wirtschafts- und sozial-geographische Untersuchung von Anton Escher. Wiesbaden: Harrassowitz.

Baccouche, Taïeb \& Mejri, Salah (eds.) (2004): Les questionnaires de l'Atlas linguistique de Tunisie. Tunis/Paris: Sud Editions/Maisonneuve \& Larose. 
Basset, André (1942): Etudes de géographie linguistique dans le sud marocain, in: Hespéris 29, 3-6 + 12 cartes.

Behnstedt, Peter (1985): Die Nordjemenitischen Dialekte - Teil 1 : Atlas. Wiesbaden: Reichert.

Behnstedt, Peter (1987): Die Dialekte der Gegend von Șa $a^{\uparrow} d a h$ (Nord-Jemen). Wiesbaden: Reichert.

Behnstedt, Peter (1997): Sprachatlas von Syrien. Kartenband. Wiesbaden: Harrassowitz.

Behnstedt, Peter (2002): La frontera entre el bereber y el árabe en el Rif, in: Estudios de Dialectología Norteafricana y Andalusi 6, 7-18.

Behnstedt, Peter (2005-2007): Materialien für einen Dialektatlas von Nordost-Marokko, in: Estudios de Dialectología Norteafricana y Andalusi 9, (I) 7-72; 11, (II) 7-57.

Behnstedt, Peter \& Woidich, Manfred (1985): Die ägyptisch-arabischen Dialekte. Band 1. Einleitung und Anmerkungen zu den Karten. Band 2. Dialektatlas von Ägypten. Wiesbaden: Reichert.

Behnstedt, Peter \& Woidich, Manfred (1987-1988): Die ägyptisch-arabischen Dialekte. Band 3. Texte. I. Deltadialekte. Band 3. Texte. II. Niltaldialekte, III. Oasendialekte. Wiesbaden: Reichert.

Behnstedt, Peter \& Woidich, Manfred (2005): Arabische Dialektgeographie. Eine Einführung. Leiden/Boston: Brill.

Behnstedt, Peter \& Woidich, Manfred (2011): Wortatlas der arabischen Dialekte (WAD). Band 1. Mensch, Natur, Faune, Flora. Leiden/Boston: Brill.

Bergsträsser, Gotthelf (1915): Sprachatlas von Syrien und Palästina, in: Zeitschrift des Deutschen Palästina-Vereins 38/3, 169-222.

Blanc, Haïm (1964): Communal Dialects in Baghdad. Cambridge, Massachussetts: Harvard University Press.

Borg, Alexander (2004): Comparative Glossary of Cypriot Maronite Arabic (Arabic-English). With an Introductory Essay. Leiden/Boston: Brill.

Brunot, Louis (1936): Notes sur le parler arabe des Juifs de Fès, in: Hespéris 22, 1-32.

Cantineau, Jean (1936-1937): Etudes sur quelques parlers de nomades arabes d'Orient (I). AIEO 2, 1118 ; (II). AIEO 3, 119-237.

Cantineau, Jean (1938a): Le parler des Drûz de la montagne Ḥôrânaise, in: Annales de l'Institut d'Etudes Orientales IV, 157-84.

Cantineau, Jean (1938b): Les parlers arabes du Département de Constantine, in: IVème congrès de la Fédération des Sociétés savantes de l'Afrique du Nord, Société historique algérienne, 849-863.

Cantineau, Jean (1946): Les parlers arabes du Ḥ̄ônan. Paris: Klincksieck.

Cantineau, Jean (1960[1955]): La dialectologie arabe, in: Etudes de Linguistique arabe. Mémorial Jean Cantineau. Paris: Klincksieck, 257-278.

Caubet, Dominique (2001): Questionnaire de dialectologie du Maghreb (d'après les travaux de W. Marçais, M. Cohen, G. S. Colin, J. Cantineau, D. Cohen, Ph. Marçais, S. Lévy, etc.), in: Estudios de Dialectología Norteafricana y Andalusi 5, 73-92.

Caubet, Dominique (2004): Les parlers arabes nomades et sédentaires du Fezzān, d'après William et Philippe Marçais, in: Martine Haak, Rudolf de Jong and Kees Versteegh (eds.), Approaches to Arabic dialects. Leiden/Boston: Brill, 67-96.

Chambers, J.K. \& Trudgill, Peter (1980): Dialectology. Cambridge: Cambridge University Press.

Cohen, David (1970[1962]): 'Koinè', langues communes et dialectes arabes, in: Etudes de linguistique sémitique et arabe. The Hague/Paris: Mouton, 105-125.

Cohen, David (1973a): Variantes, variétés dialectales et contacts linguistiques en domaine arabe, in: Bulletin de la Société Linguistique de Paris LXVIII, fasc. 1, 215-248.

Cohen, David (1973b): Pour un atlas linguistique et sociolinguistique de l'arabe, in: Micheline Galley (ed.), Actes du ler Congrès d'études des cultures méditerranéennes d'influence arabo-berbère. Alger: SNED, 63-69. 
Cohen, David (1985): Some historical and sociolinguistic observations on the arabic dialects spoken by north african Jews, in: Joshua A. Fishman (ed.), Readings in the Sociology of Jewish Languages. Leiden: Brill, 246-260.

Cohen, David \& Caubet, Dominique (2000): Un questionnaire différentiel pour la dialectologie arabe, in: Oriente Moderno, n.s. XIX (LXXX), 1 (Studi di Dialettologia Araba), 1-23.

Cohen, Marcel (1912): Le parler arabe des Juifs d'Alger. Paris: Champion.

Comrie, Bernard (2009): Maltese and the World Atlas of Language Structures, in: Bernard Comrie, Ray Fabri, Elisabeth Hume, Manwel Mifsud, Thomas Stolz \& Martine Vanhove (eds), Introducing Maltese Linguistics Selected papers from the 1st International Conference on Maltese Linguistics, Bremen, 18-20 October. Amsterdam: John Benjamins, 3-11.

De Jong, Rudolf (2000): A Grammar of the Bedouin Dialects of the Northern Sinai Littoral: Bridging the linguistic gap between the eastern and Western Arab world. Leiden: Brill.

Ferguson, Charles (1959): The Arabic Koinè, in: Language 35/4, 616-630.

Haeri, Niloofar (1996): "Why do women do this ?" Sex and gender Differences in Speech, in: Gregory R. Guy, Crawford Feagin, Deborah Schiffrin and John Baugh (eds.), Towards a Social Science of Language. Vol. I Variation and Change in Language and Society. London/New York: John Benjamins, 101-114.

Hagège, Claude (1973): Profil d'un parler arabe du tchad. Paris: Geuthner.

Heath, Jeffrey (2002): Jewish and Muslim Dialects of Moroccan Arabic. London/New York: Routledge Curzon.

Heath, Jeffrey (2003): Hassaniya Arabic (Mali): Poetic and Ethnographic Texts. Wiesbaden: Harrassowitz.

Heine, Bernd (1982): The Nubi Language of Kibera - an Arabic Creole. Berlin: Dietrich Reimer.

Holes, Clive (1980): Phonological Variation in BaÌraini Arabic: The [j] and [y] Allophones of /j/, in: Zeitschrift für Arabische Linguistik 4, 72-89.

Holes, Clive (1986): The social motivation for phonological convergence in three Arabic dialects, in: International Journal of the Sociology of Language 61, 33-51.

Holes, Clive (2006): Bahraini Arabic, in: Kees Versteegh (ed.), Encyclopedia of Arabic Language and Linguistics. Leiden/Boston: Brill, 241-255.

Kaye, Alan S. (1976): Chadian and Sudanese Arabic in the light of comparative Arabic dialectology. The Hague-Paris: Mouton.

Labov, William (1972): Sociolinguistic Patterns. Oxford: Blackwell.

Lafkioui, Mena (2007): Atlas linguistique des variétés berbères du Rif. Köln: Köppe.

Lafkioui, Mena (2009): Dialectometry analyses of Berber lexis, in: Folia Orientalia 44, 71-88.

Marçais, Philippe (1956): Le parler arabe de Djidjelli (Nord Constantinois, Algérie). Paris: AdrienMaisonneuve.

Marçais, Philippe (1975): Algérie. V - Langues, in: Encyclopédie de l'islam. Leiden/Paris: Brill \& Maisonneuve, 384-390.

Marçais, William (1961): Comment l'Afrique du Nord a été arabisée, in: Articles et conférences. Paris: Adrien Maisonneuve, 171-192.

Marçais, William and Guiga, Abderrahmân (1925): Textes arabes de Takroûna, I. Textes, transcription et traduction annotée. Paris: Leroux.

Martinet, André (1955): Économie des changements phonétiques ; traité de phonétique diachronique. Berne: Francke.

Naïm-Sanbar, Samia (1994): Contribution à l'étude de l'accent yéménite: Le parler des femmes de l'ancienne génération, in: Zeitschrift für Arabische Linguistik 27, 67-89.

Nait-Zerrad, Kamal (2005): Essai d'analyse dialectométrique appliquée au berbère, in: Studi Magrebini 3. Napoli: Università degli Studi di Napoli “L'Orientale", 229-238. 
Naït-Zerrad, Kamal (2009): Le calcul de la distance linguistique appliqué au berbère. Exploration des concepts et méthodes, in: Salem Chaker, Amina Mettouchi and Gérard Philippson (eds.), Études de phonétique et de linguistique berbères. Hommage à Naïma Louali (1961-2005). Paris: Peeters, 341-354.

Owens, Jonathan (1985): Origins of East African Nubi, in: Anthropological Linguistics 27, 229-71.

Pereira, Christophe (2010): Le parler arabe de Tripoli (Libye). Zaragoza: Instituto de estudios Islámicos.

Procházka, Stephan (1993): Die Präpositionen in den neuarabischen Dialekten. Wien: VWGÖ.

Procházka, Stephan (2003): The Bedouin Arabic dialects of Urfa, in: Ignacio Ferrando \& Juan José Sanchez Sandoval (eds.), AIDA 5th Conference Proceedings, Cadiz september 2002. Cadiz: Servicio de Publicationes Universidad de Cadiz, 75-88.

Rosenhouse, Judith (1998): Women's Speech and language variation in Arabic dialects, in: AlArabiyya 31, 123-151.

Rosenhouse, Judith (2006): Bedouin Arabic, in: Kees Versteegh (ed.), Encyclopedia of Arabic Language and Linguistics, Leiden/Boston: Brill, 259-269.

Roth, Arlette (1979): Le verbe dans le parler arabe de Kormakiti (Chypre). Paris: Geuthner.

Roth, Arlette (1994): À propos de la pondération des discriminants dans la comparaison dialectale: le cas de l'accent dans l'aire tchado-soudanaise, in: Dominique Caubet \& Martine Vanhove (eds.), Actes des premières journées internationales de dialectologie arabe de Paris. Paris: INALCO, 205-216.

Roth, Arlette (2003): Quelques aspects du fonctionnement verbal dans le parler arabe de Kormakiti (Chypre). Conservations, tâtonnements, innovations, in: Jérôme Lentin and Antoine Lonnet (eds.), Mélanges David Cohen. Paris: Maisonneuve \& Larose, 595-608.

Taine-Cheikh, Catherine (1983): Le passif en hassaniyya, in: Matériaux arabes et sudarabiques 1, 61104.

Taine-Cheikh, Catherine (1984): Les altérations conditionnées des chuintantes et des sifflantes dans les dialectes arabes, in: Comptes rendus du G.L.E.C.S. (1979-84) 24-28, 413-35.

Taine-Cheikh, Catherine (1991): L'arabe des Bidân, un dialecte bédouin de Maghreb occidental, in: Alan S. Kaye (ed.), Semitic Studies (In honor of Wolf Leslau). Wiesbaden: Harrassowitz, 1528-48.

Taine-Cheikh, Catherine (1999a): Les hassanophones du Maroc. Entre affirmation de soi et autoreniement, in: Peuples méditerranéens 79, 85-102.

Taine-Cheikh, Catherine (1999b): Deux macro-discriminants de la dialectologie arabe (la réalisation du $q \hat{a} f$ et des interdentales), in: Matériaux arabes et sudarabiques 9 (Nouvelle série), 11-51.

Taine-Cheikh, Catherine (2002): À propos de l'opposition "type synthétique" vs "type analytique" en arabe, in: Abderrahim Youssi, Fouzia Benjelloun, Mohamed Dahbi and Zakia Iraqui-Sinaceur (eds.), Aspects of the Dialects of Arabic Today. Rabat: AMAPATRIL, 234-243.

Taine-Cheikh, Catherine (2004): Le(s) futur(s) en arabe. Réflexions pour une typologie, in: Estudios de Dialectología Norteafricana y Andalusi 8, 215-238.

Taine-Cheikh, Catherine (2011): Faits de grammaticalisation et processus narratifs. Les verbes 'se (re)dresser' et 'prendre' dans l'arabe mauritanien, in: Andrei A. Avram, Anca Focseneanu and George Grigore (eds.), A Festschrift for Nadia Anghelescu. București: Editura Universitătii din Bucuresti, 490-518.

Taine-Cheikh, Catherine (à paraître): À propos de quelques expressions temporelles. Lexicalisation et grammaticalisation en hassâniyya. Essex Research Reports in Linguistics «AIDA 8 Essex Proceedings». Colchester, UK: University of Essex, 17 p.

Vanhove, Martine (2002): Conditionnelles et concessives en Arabe de Yafiৎ (Yemen), in: Werner Arnold \& Hartmut Bobzin (eds.), "Sprich doch mit deinen Knechten Aramäisch, wir verstehen es!". Wiesbaden: Harrassowitz, 755-777. 